\title{
Removal of Iron and Manganese Using Cascade Aerator and Limestone Roughing Filter
}

\author{
Azrin Mohd Sanusi ${ }^{1}$, Mohd Nordin Adlan ${ }^{1}$, M. A. Z. Mohd Remy Rozainy ${ }^{1}$ and Rhahimi Jamil ${ }^{1, a}$ \\ ${ }^{1}$ Faculty of Civil Engineering, Universiti Sains Malaysia 14300 Nibong Tebal, Pulau Pinang, Malaysia
}

\begin{abstract}
Combination between oxidation and filtration can be used for removing iron and manganese from groundwater especially when the concentrations of these metals were high. This study focused on the effectiveness of the cascade aerator and the size of the limestone filter media to remove iron and manganese from groundwater. Water samples used for this study were collected from orphanage home, Rumah Nur Kasih, Taiping. Universiti Sains Malaysia (USM) has provided a tube well of $15 \mathrm{~m}$ depth and $150 \mathrm{~mm}$ diameter for the orphanage home. However, the water cannot be used for domestic consumption due to high amount of iron and manganese at 6.48 and $1.9 \mathrm{mg} / \mathrm{L}$ which exceeded the drinking water standard of 0.3 and $0.1 \mathrm{mg} / \mathrm{L}$ respectively. Using laboratory physical model, the study has shown that the removals of iron and manganese have reduce the concentration until 0.17 and $0.2 \mathrm{mg} / \mathrm{L}$ respectively. Thus, the results from this study which utilize cascade aerator and limestone roughing filter could be implemented on site for the community to use the ground water for domestic purposes.
\end{abstract}

\section{Introduction}

Groundwater is one of the sources of water that can be used for daily needs such as bathing, cooking and washing where it represents about $97 \%$ of the freshwater resources on the Earth that are avilable for use by humans [1]. Iron and mangenese present in drinking water are not health treatening but it's a problem when the baceria exists in soil aquifers and some surface water [2]. Conventionally, iron is removed from groundwater by the processes of aeration and rapid filtration. Different mechanisms may contribute to the iron removal in filters; flock filtration, adsorptive iron removal and biological iron removal. Water containing iron can be divided into two main groups: Waters which separate iron just after aeration and waters where iron remains in the solution after aeration for endlessly long period [3]. Roughing filters are primarily used to separate fine solids from the water that are only partly or not retained at all by stilling basin or sedimentation tanks. The large filter surface area available for sedimentation and relatively small filtration rates also supports absorption as well as chemical and biological processes [4]. Universiti Sains Malaysia (USM) has provided a tube well of 15 meter depth and $150 \mathrm{~mm}$ diameter for the orphanage home called Rumah Nur Kasih, Taiping. The objective of this study is to determine the effects of the flow rates and limestone sizes on the removal of iron and manganese and to determine the amount of oxygen dissolved using the cascade aerator based on different flow rates. The scope of work for this study includes details on the parameters of

\footnotetext{
${ }^{\mathrm{a}}$ Corresponding author : nu_eiman82@yahoo.com
} 
iron, manganese and dissolved oxygen that determined through experiment on samples of water from the tube well at Rumah Nur Kasih, Taiping.

\section{Materials and Methodology}

\subsection{Study area}

Orphanage house, Rumah Nur Kasih, Taiping is inspired by the committee to create a home that is perfect for placing orphans and the poor. A committee was established to achieve the objective, and an old mosque has been applied for and received approval from religion and treasury offices to house all the selected orphans and the poor. After obtaining a consensus, then on 1st June 2010 the committee agreed to name this organization with the name of Nur Kasih Welfare Organisation, Taiping and named orphanages and poor in the name of Rumah Nur Kasih, Taiping. Location to take water samples is at Rumah Anak-Anak Yatim dan Miskin Nur Kasih, Taiping, Perak.

\subsection{Description of instruments}

Samples for analysis in a pilot study should be collected carefully to make sure the most representative sample possible is obtained. Water samples were taken once a week using five clean bottles. Equipment was used to take the water samples is bottles and hosepipe. The measurement of total iron and manganese was made using Method Hach DR 2800 with standard 3500FeB (APHA, 2014), where for iron the DR 2800 entered the 265 program and for manganese selected 296 program. The DR2800 were installed into the cascde aerator shown at Figure 1 to measure the dissolved oxygen and also the total iron and manganese.

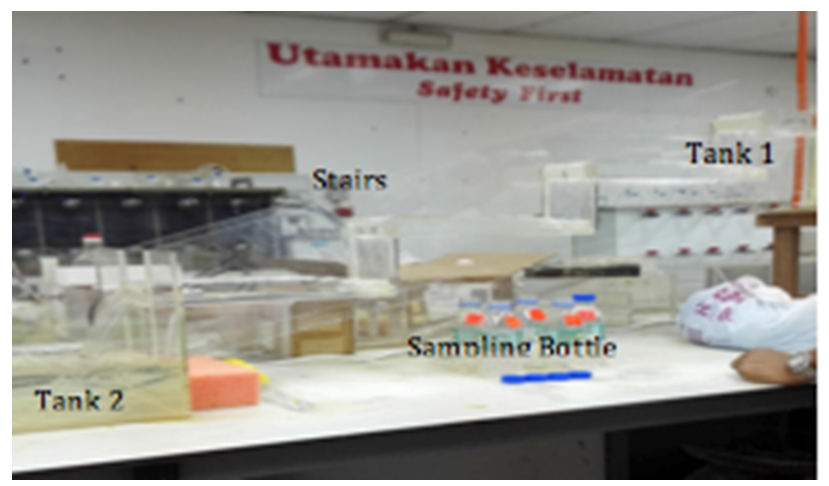

Figure 1. Cascade aerator model.

\subsection{Measurement technique}

Pilot study has been done to make the most representative sample that possible for the study obtained. Water samples were taken once a week using five clean bottles. After water sample arriving at the laboratory, experiment at cascade aerator shown at Figure 1, must continue to avoid the water exposed to air for long time. The measurement of total iron was made using Method Hach DR 2800 with standard 3500FeB (APHA, 2014). The DR 2800 entered the 265 programs. The two clean cells, one cell was filled with distilled water (blank) and another one with a water sample. The cell with sample was added with one Ferro Ver Iron Reagent Powder Pillow. When the colour of the regent turns to orange its show the iron was presented. DR2800 also used to determine manganese, where after stored the programs, 296 Manganese test was selected. A violet colour will develop if manganese is present. Roughing filtration can be considered as a major pre-treatment process for wastewater, since they 
could efficiently separate fine solid particles over prolonged periods without addition of chemicals. The roughing filter size in this research is $29 \times 6.5 \times 6$ inches. There three sizes of filtration media had been chosen are $12.5 \mathrm{~mm}-10 \mathrm{~mm}, 5 \mathrm{~mm}-3.35 \mathrm{~mm}$, and $2.36 \mathrm{~mm}-0.6 \mathrm{~mm}$, suggested by Aziz and Smith $[5,6]$ the limestone was sieved a size between 2.36 and $4.75 \mathrm{~mm}$. Figure 2 shows the scematic diagram of filtration media that has been built as a model.

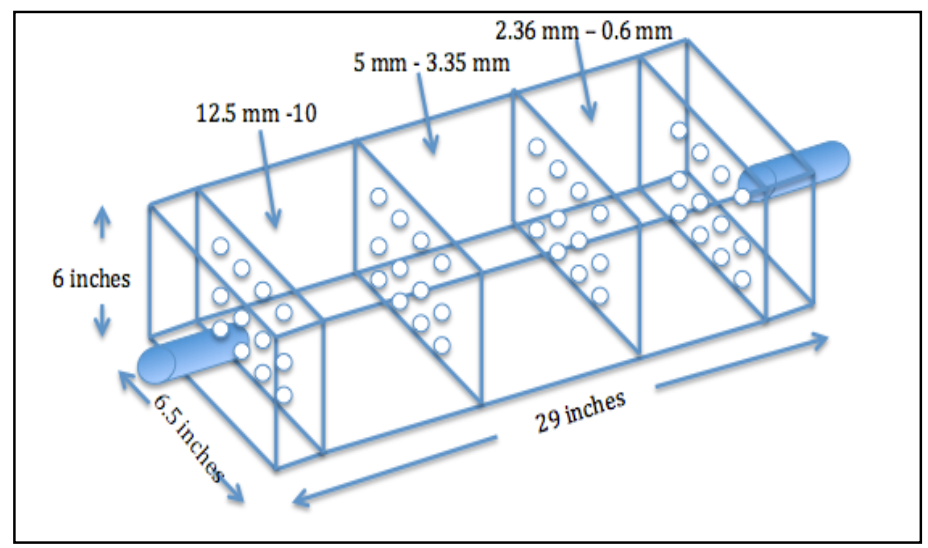

Figure 2. Scematic diagram for limestone roughing filter.

\section{Results and Discussion}

The results obtained for iron and manganese test were using DR2800. The test results are based on samples taken from Rumah Nur Kasih, before and after filtration. For iron and manganese, flow rates used were 25, 10 and $40 \mathrm{~L} / \mathrm{min}$. According to Rathinakumar et al. [2], the flowrate that had chosen between $0.003 \mathrm{~m} 3 / \mathrm{s}$ until $0.021 \mathrm{~m} 3 / \mathrm{s}$, means the flow rate increment ie proportional to the aeration improvement. The graph is divided into two according to the mix trial. First graph the data analysed between percentage removals after filter against limestone size and the second graph is percentage removals after filter against flow rate. Based on results mix trial, the experiment continued using flow rate $25 \mathrm{~L} / \mathrm{min}$ and limestone size $2.36 \mathrm{~mm}-0.6 \mathrm{~mm}$ and the results is satisfactory and achieve the standard referred to the DOE Water Quality Index Classification. Figures 3 and 4 respectively for iron and manganese represents the aeration efficiency of a stepped channel with flow rate $25 \mathrm{~L} / \mathrm{min}$ while constant step rise.

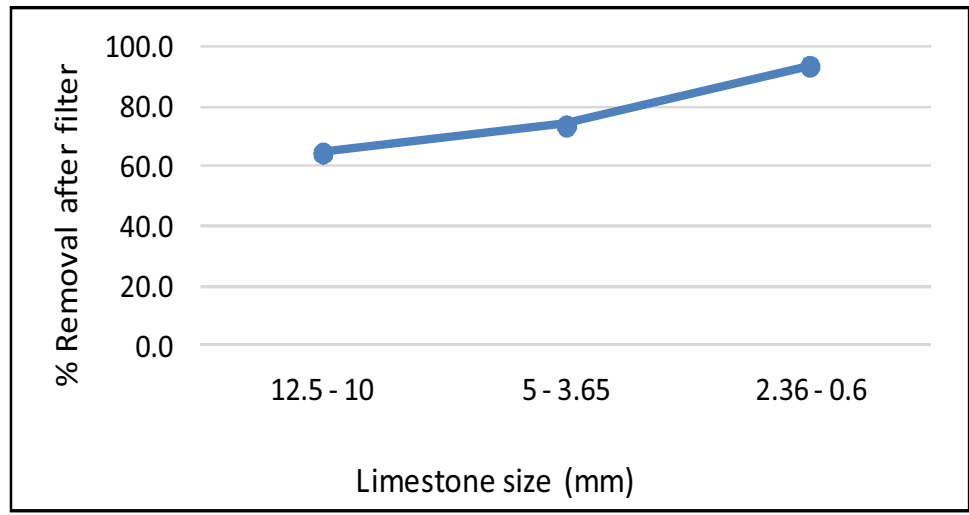

Figure 3. Percentage removal of iron against limestone size with flow rate $25 \mathrm{~L} / \mathrm{min}$. 


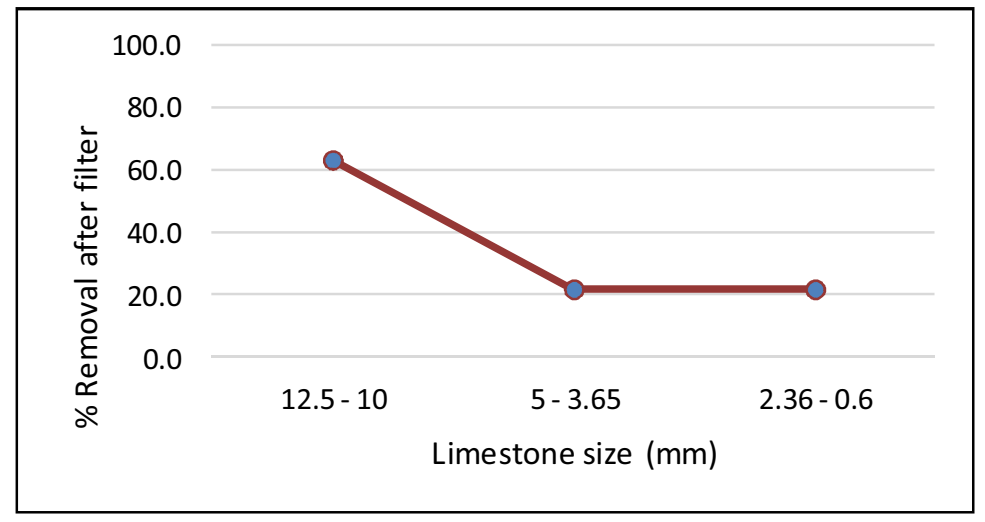

Figure 4. Percentage removal of manganese against limestone size with flow rate $25 \mathrm{~L} / \mathrm{min}$.

Figures 5 and 6 respectively for iron and manganese show the filtration efficiency with limestone size $2.36 \mathrm{~mm}-0.6 \mathrm{~mm}$ with different flow rates. The flow rates are 10,25 and $40 \mathrm{~L} / \mathrm{min}$. From graph, the highest iron removal is at flow rate $25 \mathrm{~L} / \mathrm{min}$.

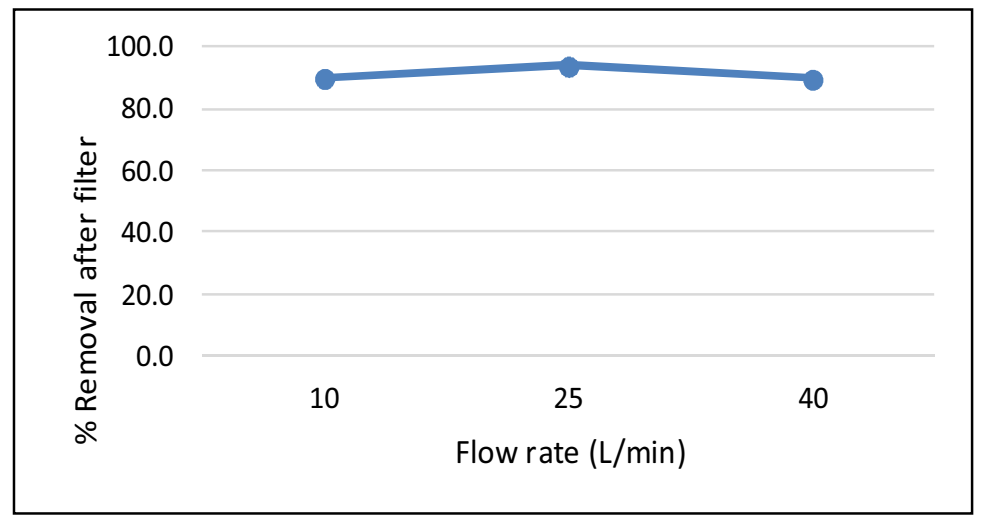

Figure 5. Percentage removal of iron against flow rate with limestone size $2.36 \mathrm{~mm}-0.6 \mathrm{~mm}$.

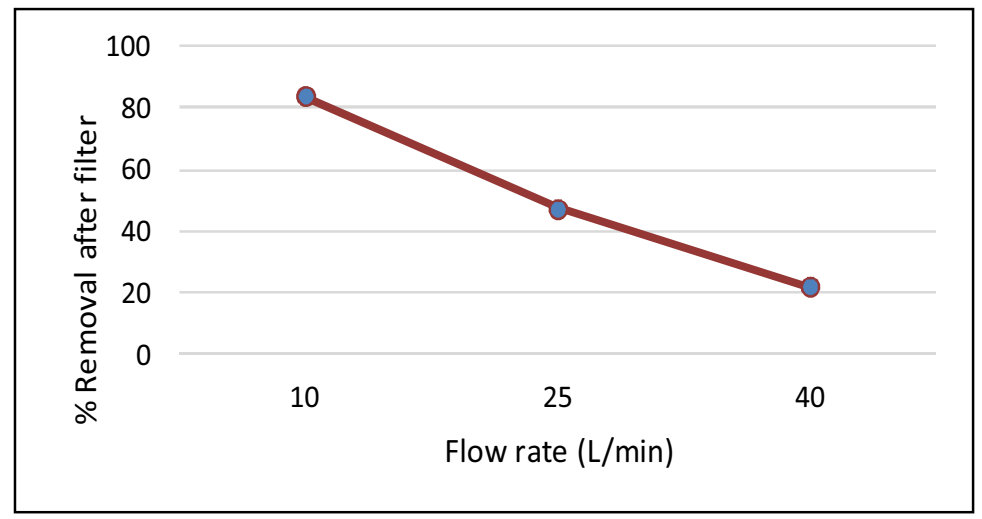

Figure 6. Percentage removal of manganese against flow rate with limestone size $2.36 \mathrm{~mm}-0.6 \mathrm{~mm}$. 
Table 1 shows the increasing DO obtained from the tank 1 to tank 4. DO value obtained at the bottom of the tank is at a level II according to standard shown of DOE Water Quality Index Qualitification. In theory, the dissolved oxygen is an indicator of the degree of contamination of water because the lower the dissolved oxygen, the more polluted the water.

Table 1. The results of DO obtained.

\begin{tabular}{|c|c|c|c|c|c|}
\hline \multicolumn{7}{|c|}{ Dissolved Oxygen, DO (mg/L) } \\
\hline Sample & $\mathbf{1}$ & $\mathbf{2}$ & $\mathbf{3}$ & $\mathbf{4}$ & $\begin{array}{c}\text { Flowrate } \\
(\mathbf{L} / \mathbf{m i n})\end{array}$ \\
\hline 1 & 4.0 & 5.4 & 5.9 & 6.2 & 12 \\
\hline 2 & 3.5 & 5.1 & 6.0 & 6.4 & 22 \\
\hline 3 & 6.5 & 6.9 & 7.3 & 7.9 & 25 \\
\hline 4 & 3.5 & 5.3 & 6.4 & 6.8 & 32 \\
\hline
\end{tabular}

\section{Conclusions}

This study was utilized the cascade aerator and limestone roughing filter could be implemented on site for the community to use the ground water for domestic purposes. Based on the results its shows that from iron parameter, the highest removal is $0.17 \mathrm{mg} / \mathrm{L}$ while the highest removal for manganese is 0.2 $\mathrm{mg} / \mathrm{L}$ and the highest DO value is $6.8 \mathrm{mg} / \mathrm{L}$ at $32 \mathrm{~L} / \mathrm{min}$ after pumping the water sample by using different flow rates.

\section{Acknowledgement}

The authors would like to acknowledge Ministry of Education Malaysia for providing LRGS grant No. 203/PKT/6726001 - Riverbank Filtration for Drinking Water Source Abstraction to fund this research.

\section{References}

[1] E. Lopez-Gun and W.T. Jarvis, Groundwater governance and the low of the hidden sea, Water Policy, 11(6), 742-762, (2009).

[2] V. Rathinakumar, G. Dhinakaran and C.R. Suribabu, Assessment of aeration capacity of stepped cascade system for selected geometry, Int. J. of ChemTech Research, 6(1), 254-262, (2014).

[3] R. Munter, H. Ojaste and J. Sutt, Complexed iron removal from groundwater, J. of Environmental Engineering, 131, 1014-1020, (2005).

[4] O. Nkwonta and G. Ochieng, Roughing filter for water pre-treatment technology in developing countries: A review, Int. J. of Physical Sciences, 4(9), 455-463, (2009).

[5] H.A. Aziz and P.G. Smith, The Influence of $\mathrm{pH}$ and coarse media on manganese precipitation from water, Water Research, 26(6), 853-855, (1992).

[6] H.A. Aziz and P.G. Smith, Removal of manganese from water using crushed dolomite filtration technique, Water Research, 30(2), 489-492,1996. 